\title{
Тищенко В. В.
}

\section{ГЕНОМ, РАСШИФРОВКА ДНК, ХИЗНЬ: НАУЧНЫЕ, ТЕХНОЛОГИЧЕСКИЕ И ЭТИЧЕСКИЕ ПРОБЛЕМЫ}

Tishchenko V. V.

GENOME, DNA DECODING, LIFE: SCIENTIFIC,
TECHNOLOGICAL AND ETHICAL ISSUES

В статье рассматриваются некоторые связанные с геномом вопросы философского, правового, этического и технологического характера, дается анализ международно-правовых принципов и норм в этой области, поднимаются вопросы его регулирования российским правопорядком. Предпринимаются попытки представить юридический взгляд на «жизнь», а также провести соотношение с «правом на жизнь». Делается вывод о том, что правовое регулирование отношений в области генома характеризуется определенной неупорядоченностью и противоречивость.

Ключевые слова: геном, правопорядок, жизнь, субъект права, международная правовая система, национальная правовая система.

The article deals with some genome-related issues of philosophical, legal, ethical and technological nature, presents the analysis of international legal principles and norms in the area and raises issues of its regulation by the Russian law and order. The author attempts to provide a legal view of the 'life' concept as well as to contrast it with the right to life. The author concludes that the legal regulation of genome-related issues is characterized by ambiguity and vagueness.

Keywords: genome, legal order, life, subject of law, international legal system, national legal system.

В рамках настоящей работы мы хотели бы затронуть одну из важнейших проблем в области правового регулирования вопросов, связанных с генетическими исследованиями и технологиями - проблему неопределенности права. Неопределенности, выражающейся, в том числе в непоследовательности регулирования, в размытом правовом статусе явлений, которые не закрепились прочно в общественной практике. Явление, которое также связано с неопределенностью, но ей собственно не является, можно было бы назвать как неполную разработанность данного вопроса юриспруденцией. В правовом регулировании недостаточно обозначить лишь общее направление, хотя надо признать, что без него никоим образом нельзя обойтись. Многие правопорядки проявили более предметный интерес к вопросам правового регулирования данных областей жизни. Российский национальный правопорядок в настоящий момент, на наш взгляд, к данной категории не относится, хотя шаги в этом направлении предпринимаются. Пробелы правового регулирования в обозначенной области могут иметь тяжелые и далеко идущие последствия. Полагаем, что определяющую роль в правовом регулировании данных вопросов должен выполнять именно международный правопорядок.

Кроме собственных проблем права, затронем некоторые этические и технологические вопросы, касающиеся нашей темы.

Определившись с направленностью, считаем необходимым сказать, что данная статья является своего рода введением. Заявленная тема действительно является обширной, что не помешает предоставить несколько предварительных замечаний - некий общий юридико-философский взгляд на проблемы.

Предварительно стоить отметить, что это прежде всего исследование юридического профиля в рамках проекта «Выявление проблем правового регулирования 
в сфере использования генетической и геномной информации». Автор настоящего исследования не обладает достаточными знаниями в естественных науках, чтобы делать какие-либо авторитетные выводы в рамках биологии, химии, медицины или генетики. Данное работа представляет собой прежде всего юридикофилософский взгляд, который будет по мере необходимости и компетентности использовать достижения иных областей знания. Сказанное нисколько не означает, что мы снимаем с себя всякую ответственность.

В начале нашего анализа мы хоти обратить внимание на этическую сторону нашей проблемы. Мораль оказывает влияние на состояние государства и права (правопорядка) при формировании и функционировании, неизбежно впоследствии сама начинает подвергаться обратному воздействию. Вопросы права очень тесно связаны с этической проблематикой. Поэтому в данной части работы мы бы хотели показать небольшой обзор генезиса этических воззрений.

Историю права можно представить через все новые и новые области жизни, включающихся в предмет правового регулирования. Усложняющиеся общественные отношения требовали их правового опосредования. Сформировываются новые области знания, такие как генетика и геномика. Произошел качественный скачок в медицине. Новые технологии включаются в предмет правового регулирования. В 1971 году В.Р. Поттер употребляет термин «биоэтика» - направление научной мысли на стыке медицины, биологии, философии и юриспруденции. Отношения данного типа начали входить в предмет правового регулирования только относительно недавно, и в разных странах этот процесс шел неравномерно. Нельзя не сказать о том, что интерес к наследственности возник у ученых на рубеже XIX-XX веков. И юриспруденция не осталась в стороне: ориентируясь на достижения евгеники, сформировались целые теории в рамках уголовного права и криминологии. Ж. Гобино была разработана «расовая теория» происхождения государства. Реализация этих идей порой приобретала ужасные и уродливые формы. Режим Третьего Рейха имел ярко выраженный расовый характер. Он основывался на идеях превосходства одной расы над другими, что в конце концов привело к холокосту. Предпринимались попытки установить «чистоту крови», а немецкие ученые ставили опыты над людьми в попытке получить преимущество в войне.
С 1946 по 1947 годы продолжался процесс по делу медицинских преступлений нацистских ученых Второй Мировой войны. Подсудимые обвинялись, в частности, в принудительных медицинских опытах над заключенными концлагерей, в том числе в экспериментах с заражением сыпным тифом, малярией, туберкулезом и гепатитом, с реакцией на низкие температуры, по пересадке органов. Из 23 обвиняемых 7 были приговорены к смертной казни, 5 к пожизненному заключению, 4 к тюремным срокам различной степени длительности, а 7 были оправданы [21]. Нельзя не упомянуть также и «Операция Тиргартенштрассе 4» или Программа умерщвления Т-4, в соответствии с которой уничтожались также и люди, которые страдали различными генетическими заболеваниями.

Отметим, что в первой половине XX века Третий Рейх столкнулся с серьёзными трудностями, пытаясь определить «чистоту крови». В Законе о гражданстве рейха появилось понятие «еврей», но для определения «еврейства» прибегали к религиозным основаниям. Они так и не нашли именно «расовый» способ провести различия между евреями и не евреями [17, с. 107-108]. К слову, в 2020 году можно узнать так называемый «генетический паспорт» человека. Можно только предположить о последствиях, которые могли бы быть, окажись в их распоряжении эти технологии.

Праву необходимо со всей ясностью задать рамки дозволенного, спрогнозировать благоприятные и неблагоприятные последствия, чтобы человечество было готово заранее. Правовое регулирование не должно осуществляться реакционного и хаотично, ибо в таком случае цель его достигнута не будет, а последствия могут быть самые непредсказуемые.

Этико-юридические проблемы биомедицинских технологий рассматриваются биоэтикой - междисциплинарной области исследований, соединяющую в себе знания в области медицины, биологии, генетики с одной стороны и философией и правом, с другой. В рамках биоэтики переплетаются социо-гуманитарные и естественные науки. Употребленный американским биохимиком во второй половине XX века термин «биоэтика» нашел свое место в научном дискурсе. «Биоэтика как знание с 70-х по 90-е годы XX века развивалась как дисциплина описательная - она фиксировала коллизии, которые возникают между людьми, вынужденными принимать решение в ситуациях, 
жизненно важных для них или для другого человека, когда они были связаны с развитием медико-биологического знания. ... С течением времени биоэтика начала переходить от описания к нормативному регулированию»[8]. Именно нормативному аспекту мы бы хотели уделить наше внимание. Включение в общественную практику новых технологических решений требует тщательного этико-правового обсуждения. Во-первых, современные научные открытия в области естественных наук содержат в себе потенциальные угрозы, по масштабам и последствиям прежде не мыслимым. Во-вторых, усложнилось правовое регулирование общественных отношений. Учитывая также повышение уровня правовой культуры и правосознания населения повлекло за собой также и повышение требований как к проведению исследований, так и внедрению новых технологий.

Возросший интерес к данным проблемам отлично демонстрирует то обстоятельство, как активно проводятся различного рода международные конгрессы и конференции, а в большинстве стран Европы и Америки созданы национальные комитеты по биоэтике, в США и Франции они организованы при президентах этих государств. Практически все международные организации - ЮНЕСКО, Всемирная организация здравоохранения, Всемирная медицинская ассоциация, Совет Европы - имеют в своем составе комитеты или комиссии, постоянно занимающиеся вопросами биоэтики [16, с. 771].

В 60-х годах XX века был сформулирован важнейший для биоэтики принцип «автономии личности» пациента, обосновывающий право человека участвовать в качестве самостоятельного субъекта и принимать решения, касающиеся его здоровья. Также было выработано важнейшее биоэтическое правило «добровольного информированного согласия», о котором подробнее мы поговорим немного позднее.

Эксперименты над людьми проводились не только при тоталитарных режимах. Совсем недавно стало известно, что в ходе экспериментов с 1946 по 1948 годы американские ученые специально заражали жителей Гватемалы венерическими заболеваниями с целью установления воздействия пенициллина на сифилис. Около 700 человек, которые ничего об этом не знали, участвовали в этом эксперименте [28]. Они были объектом воздействия американской науки. США только в 2010 году принесло извинения за данные действия.
В 1964 году на 18-ой Генеральной Ассамблее Всемирной медицинской ассоциации была принята Хельсинская декларация об этических принципах проведения медицинских исследований с участием человека в качестве субъекта [29]. Человеческое тело перестает быть просто объектом. В исследованиях кроме интереса публичного появляется интерес частный. Уже он начинает оказывать влияние на процесс исследования и технологию.

11 марта 2020 года Всемирная Организация Здравоохранения объявила пандемию нового типа коронавируса COVID-19. По имеющейся информации на разработку вакцины от инфекции может уйти более одного года. И это при условии, что разработкой занимаются ученые по всему миру. По словам специалистов, уже известно, какие гены нужно использовать для создания вакцины. Но сначала лекарство будет несколько месяцев проходить доклинические испытания на животных, затем ученые перейдут к тестам на добровольцах [9]. Данный процесс был не всегда продолжительным, что можно объяснить, в том числе отсутствием ограничений - требований к проведению испытаний. В уже упомянутую нами Хельсинскую декларацию в 1975 году были внесены изменения, касающиеся ужесточения порядка проведения клинических испытаний.

«Публикация Хельсинкской декларации стимулировала интенсивное теоретическое исследование этических проблем экспериментирования на человеке, которое представляет собой одно из важнейших направлений современной биоэтики»[7]. Последние изменения в декларацию были внесены в 2013 году.

«В конце 80-х годов в условиях бурного развития медико-биологических наук и опасности негативных последствий их практического применения Совет Европы принял решение о создании соответствующего общеевропейского документа. В 1993 г. Генеральная ассамблея Совета Европы приняла Конвенцию по защите прав и достоинства человека в связи с применением биологии и медицины. В настоящее время к этой конвенции присоединилось большинство европейских стран» [16, с. 772].

Параллельно с развитием правил проведения исследований и внедрения технологий развитие естественно-научного знания продолжалось. В 1990 году стартовал международный научно-исследовательский проект «Геном человека», в рамках которого были поставлены амби-

\section{3}

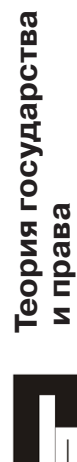


циозные цели. В частности, ученые стремились определить последовательность нуклеотидов в человеческом геноме, идентификация 20 000-25 000 генов ДНК и т.д. [25]. Была расшифрована нуклеотидная последовательность всех хромосом человека. Был создан открытый банк генокода.

Геном - совокупность наследственного материала, заключённого в клетке организма. Геном содержит биологическую информацию, необходимую для построения и поддержания организма. Большинство геномов, в том числе геном человека и геномы всех остальных клеточных форм жизни, построены из ДНК. Первоначальный смысл этого термина указывал на то, что понятие генома, в отличие от генотипа, является генетической характеристикой вида в целом, а не отдельной особи. С развитием молекулярной генетики значение данного термина изменилось, и сегодня под «геномом» понимают совокупность наследственного материала конкретного представителя вида [12].

Нельзя обойти стороной проблему информированного согласия, о котором мы вскользь упоминали. Уже к 1999 году более 300 миллионов биологических образцов хранилось в Соединенных Штатах в самых разных государственных и частных хранилищах, большая которых была собрана во время проведения клинических и хирургических процедур. При относительной простоте сбора генетической информации возникает большое количество проблем правового, этического и социального характера, которые связаны с конфиденциальностью, раскрытия результатов исследования, управления биобанками и др. Отмечается, что правило информированного согласия должно гарантировать, что лица, участвующие в исследовании, понимают его цель и добровольно соглашаются подвергать себя потенциальным исследовательским рискам [4, p. 12-13].

Безусловно, необходимо согласиться с тем, что отсутствие надлежащего информированного согласия исследования в области генома могут быть поставлены под угрозу, поскольку доверие к исследованиям со стороны участников будет подорвано. А без участия людей, которые будут согласны предоставить материал для исследования, проводить последние будет в большой мере затруднительно. Поэтому информированное согласие призвано защитить интересы, как участников исследования, так и само исследование. Риски, связанные с генетической информацией выходят далеко за рамки стандартных представлений потенциального вреда для участников исследования, ведь знание генетической информации может влечь за собой различного рода дискриминации и притеснения участников исследования [3, р. 451]. В частности, исследуемые порой даже не задумываются о потенциальных опасностях. В одной из работ ученые пришли к выводу, что ни один из участников исследования не испытывал волнения по поводу конфиденциальности своих генетических данных [1, p. 50].

Мы плавно переходим к предметному обсуждению юридической стороны вопроса. Широко известно выражение Ульпиана о том, что публичное право есть то, которое относится к положению римского государства; частное - которое к пользе отдельных лиц. Между публичным и частным правом с одной стороны и публичным и частным интересом нельзя автоматически ставить тождество. Как в публичном праве может удовлетворяться частный интерес, так и в частном - публичный. Сталкиваясь, частный и публичный интерес находят точки соприкоснования. Это столкновение во многом определяет содержание нормативной системы. Например, в правопорядке с доминированием публичного интереса частные отрасли права будут под его заметным влиянием, если частное право в принципе будет в нем существовать. История правового регулирования в области генома свидетельствует о движении от приоритета публичного к приоритету частному.

Предложения об унификации правового регулирования генной инженерии озвучиваются в международном сообществе. Так, профессор юридического колледжа Университета штата Аризона Гари Марчант, заявил, что в настоящее время правительство США регулирует генную инженерию, прежде всего, из-за влияния социальных и этических норм, контролируя финансирование исследований. США в 2017 году потратили 518 миллионов долларов только на генетические исследования, контролируя финансирование исследований. По данным ООН 2009 года из 192 стран 133 не имели каких-либо правовых норм, регулирующих технологии генетической модификации [23. с. 92].

По состоянию на 2020 г. Организацией объединенных наций были приняты несколько документов, затрагивающих вопросы биоэтики. Отметим некоторые из них. Во-первых, в 1997 году ООН была принята Всеобщая декларация о геноме человека и правах человека. Во-вторых, в 2003 году - Международная декларация о 
генетическихданныхчеловека. В-третьих, в 2005 году - Всеобщая декларация о биоэтике и правах человека.

Всеобщая декларация о геноме человека и правах человека закрепляет несколько важных моментов. В преамбуле Декларации 1997 года закрепляется, что «научные исследования по геному человека и практическое применение их результатов открывают безграничные перспективы для улучшения здоровья отдельных людей и всего человечества». В статье 10 закрепляется, содержится этическая максима, касающаяся генетических исследований: «Никакие исследования, касающиеся генома человека, равно как и никакие прикладные исследования в этой области, особенно в сферах биологии, генетики и медицины, не должны превалировать над уважением прав человека, основных свобод и человеческого достоинства отдельных людей или, в соответствующих случаях, групп людей» [11]. В соответствии с этим нормативным положением можно сделать простое логическое заключение о том, что в настоящий момент никакие преимущества, которых можно достигнуть при проведении генетических исследований, не могут служить обоснованием для умаления прав человека.

Геном человека провозглашается достоянием всего человечества. Но кому все-таки принадлежит геном? Есть ли у лица права господства над геномом, подобно собственности, которой можно распоряжаться по своему усмотрению? На эти вопросы юридической науке только предстоит ответить. В настоящий момент же ограничимся лишь указанием на эту проблему.

Международная декларация о генетических данных человека устанавливает правила работы с генетическим материалом: принципы сбора, обработки, использовании и хранении генетических данных человека, протеомных данных человека и биологических образцов, на основе которых они получены [18]. «Каждое лицо имеет уникальный генотип, определяющий его идентичность, которая также формируется под воздействием образования, экологии, социальных, духовных, культурных и личностных связей с другими людьми и предполагает элемент свободы. Генетические данные личности имеют особый статус, поскольку они могут указывать на его генетическую предрасположенность, оказывать воздействие на семью, включая потомков, и даже всю этническую группу; содержать информацию, значение которой было не- известно в момент взятия биологических образцов; иметь культурное значение для отдельных лиц или групп лиц» [15, с. 180]. «Геном человека должен быть сохранен и огражден от необоснованного вмешательства, а все наличное биоразнообразие видов и экосистем надежно защищено» $[27$, с. 11].

«Бурное развитие и беспрецедентное могущество биомедицинских технологий в последние десятилетия ведут к тому, что естественный жизненный процесс индивида от рождения (и даже от зачатия) до самой смерти становится все более опосредуемым и контролируемым, т.е. организуемым и управляемым социально и технологически. При этом по отношению к пациенту (испытуемому) медицинские вмешательства приобретают все более инвазивный, глубокий, а нередко и агрессивный характер» [20, с. 267-270].

Во Всеобщей декларации по биоэтике и правах человека закрепляются основные принципы правового регулирования общественных отношений в области биоэтики. Это принципы равенства, недискриминации, уважения культурному разнообразию, неприкосновенности частной жизни и конфиденциальности, защиты будущих поколений и др. Статья 19 рекомендует создавать «независимые, многодисциплинарные и плюралистические комитеты по этике», в ст. 20 указывается на необходимость проведения соответствующей оценке рисков, касающихся медицины, наук о жизни и связанных с ними технологий, а ст. 22 устанавливает, что «Государствам следует принимать все надлежащие меры законодательного, административного или иного характера для реализации принципов, изложенных в настоящей Декларации, в соответствии с международными нормами в области прав человека. Такие меры следует дополнять соответствующей деятельностью в сфере образования, профессиональной подготовки и общественной информации» [10]. Иными словами, данная декларация определяет общее направление правового регулирования для национальных правопорядков.

Некоторые авторы отмечают, что «можно констатировать назревание серьезной проблемы отсутствия правового регулирования генной инженерии и биомедицинских технологий. Поэтому необходимо начать с формирования международно-правовых принципов, которые дадут начало построению нормативно-правовой базы и сформируют единообразный подход во всех странах, проводящих в настоящее время научные исследова-
35

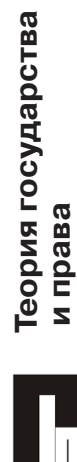


ния в области генной инженерии» [23, с 95]. И хотя мы не можем в полной мере согласиться с тем, что правовое регулирование в данных областях отсутствует, признаем, что ему есть куда совершенствоваться. Скорее необходимо достигать более последовательной реализации международных принципов и норм в международном правопорядке.

Существуют области человеческой деятельности, принципы осуществления которой должны быть едины. Регулирование в данных областях должно быть унифицировано, а культурные различия учитываться на уровне «осуществление» «не-осуществление». Если национальный правопорядок желает осуществлять исследования в области генома, то он должен подчиняться жестким и ясным правилам, а в обратном случае - не осуществлять работу с генным материалом. Это требуется по причине потенциальных негативных последствий, которые будут обнаружены впоследствии. Поэтому возможно, что следует типовой нормативноправовой акт, обязательный к принятию для тех правопорядков, который имеют намерение работать с геномом.

Нельзя упустить из виду то обстоятельство, что международный правопорядок в последнее время испытывает некоторые трудности. В.Д. Перевалов справедливо отмечает, что нельзя не замечать «негативных тенденций в международном праве», связанных, в том числе с повышенной неопределенностью и турбулентностью [22, с. 14].

Исследование, лечение и диагностика генома человека должны проводиться лишь после связанных с ними потенциальных опасностей и преимуществ. Прежде чем проводить какие-либо операции с геномом конкретного человека можно только с согласия последнего, уведомив последнего о результатах и его последствиях. Также устанавливается возможность взыскания компенсации за причинения ущерба, причиненного в результате «непосредственного и детерминирующего» воздействия на геном.

В качестве примера ориентированности российского национального правопорядка на международные стандарты отметим, что Россия в 2006 году был создан Российский комитет по биоэтике при Комиссии РФ по делам ЮНЕСКО, на который в соответствии с Положением о Российском комитете по биоэтике при комиссии Российской Федерации по делами ЮНЕСКО возложены следующие задачи: 1. Участие в деятельности, в том числе предпринимаемой по линии Комиссии и
ЮНЕСКО, по оценке этических, правовых, научных и социальных проблем, касающихся исследовательских проектов и связанных с ними технологий, объектом которых является человек; 2. Участие в подготовке законопроектов Российской Федерации, затрагивающих проблемы биоэтики; 3. Экспертиза проектов международно-правовых документов, законодательных и нормативных актов Российской Федерации на предмет их соответствия обязательствам Российской Федерации по биоэтике; 4. Экспертиза документов, относящихся к компетенции Комитета и направленных на согласование министерствами и ведомствами Российской Федерации; 5. Мониторинг соблюдения международных и внутригосударственных биоэтических норм при проведении научных исследований и в практическом здравоохранении, содействие процессам ратификации Российской Федерацией международных документов в области биоэтики; 6. Выявление и анализ новых тенденций развития биоэтических норм, а также международной практики в этой области с целью адекватной реакции российских министерств и ведомств на происходящие изменения [24]. Иными словами, задачами комитета являются систематический анализ этических аспектов медицинских наук, наук о жизни и инновационной политики в области здравоохранения. Формулировка заимствована с небольшими изменениями стилистического характера из Руководства № 1 по созданию комитетов по биоэтике, принятого Отделом этики, науки и технологий Организации Объединенных Наций повопросами образования, науки, культуры [26].

Генные технологии корректируют наше представление о казалось бы уже устоявшихся в нашем сознании явлениях. Юриспруденция не является исключением. Развитие естественных наук обязывает изменять правовое регулирование. Порой, изменяя наше восприятие даже устоявшихся правовых категорий.

Что право понимает под жизнью и как она соотносится с правом на жизнь? Существует множество философских концепций, по-разному определяющих жизнь. Даются самые различные трактовки понимания этого явления. Но как мы сможем сформулировать хоть какуюнибудь серьезную проблему, если не определимся с тем, где мы, собственно, будем их искать. Ведь без определенности мы не только не сможем отыскать ничего мало-мальски стоящего, но более того - направимся по ложному следу. Мы 
будем решительно думать, что достигли успеха, блуждая при этом в темноте.

Говорить мы будем о жизни юридическом смысле. Речь не будет вестись о «жизни правовых явлений» как о способе их бытия, но о том, как позитивное право понимает осуществление человеческой жизни. На наш взгляд, самый главным вопросом, касающимся «жизни», представляется вопрос определения понятия. Остальные проблемы - моменты возникновения жизни и её прекращения будут проблемами второго порядка, хотя порой иногда и кажется, что они имеют для юриспруденции важнейшее значение.

Изначально может показаться, что в праве «жизнь» и «право на жизнь» совпадают по своему объему. Мы, безусловно, соглашаемся с тем, что «право на жизнь должно рассматриваться как особое субъективное право в соответствии с общей логикой исследования любого субъективного права, так как является в определенном смысле частным проявлением более общего явления» [5, с. 64]. Также отметим следующее. Жизнь как юридическая категория связана не только с непосредственным правом на жизнь, хотя с ним также теснейшим образом. Это вопрос бытия человека как субъекта права, который проявляет себя в правоотношении. Жизнь делает возможным обладание или необладанием человеком правами. Условие существование человека в правовом поле, отсутствие которого делает неактуальным все остальные смыслы. При этом нельзя отождествлять физическое лицо как субъекта права непосредственно с его телесным проявлением было бы решительно неверным решением.

Правопорядком гарантируется осуществление самых различных прав: право собственности, право на безопасную экологическую среду, право на справедливый суд. Право на жизнь находится в одном ряду с другими правами субъекта. Причем в различные исторические периоды права гарантировались и охранялись по-разному. В таком случае «право на жизнь» становится лишь одним из, а не единственным необходимым. Мы же занялись поиском основания - юридической категории, делающей возможность человеку быть субъектом права как физическому лицу. Становится очевидным, что в «праве на жизнь» в жизнь вкладывается несколько иной смысл - специальноюридический. Это необходимо для того, чтобы стройная система юридических конструкций не смешалась в процессе правореализации и правоприменения. Так что же мы ищем?
Концепция естественного права утверждает, что таким основанием является либо природа человека, либо возможности его всемогущего разума, либо какаято сверхъестественная сущность. Позитивизм находит своё основание в суверенной и произвольной воле суверена.. Историческая школа попытается найти основание в «народном духе», а социологическая - в реально-осуществляемых общественных отношениях. Однако все эти основания имеют внешний по отношению к правопорядку характер. И поскольку они имеют характер внешний, то оказывать могут в разное время также различный характер, определяя внешний облик права и государства.

Искать условие существования необходимо внутри самого правопорядка, не оглядываясь на внешние авторитеты. Надо признать, что «внешнее» может оказывать на правопорядок настолько сильное влияние, при котором может показаться, что именно оно и является определяющим. Условием существования государства и права (правопорядка) является их системная взаимосвязь, а также базирование на единых принципах. Единство, основывающееся на единообразных принципах организации государства и права, отсутствие которых превращает их в псевдо-государство и псведо-право. Данные псевдо-феномены не так редки в истории общественных отношений: появляются, маскируясь под правопорядок иной механизм социальной регуляции со своими собственными принципами и закономерностями.

Правопорядок, предстающий перед нами как методологическое единство государства и права, волен самостоятельно устанавливать самостоятельное понимание «права на жизнь». Однако делать он это может, учитывая ограничения, задаваемые им самим - его существом, то есть механизмами организации его деятельности. Поскольку одним из главных принципов правопорядка является его осуществимость, то есть такое состояние государства и права, при котором требования предписаний правовых норм необходимо исполняются (причем юридические инструменты должны использоваться по своему назначению) - приводятся в движениями субъектами права, не возникают неразрушаемые правовые коллизии и т.д. То есть вне зависимости от того, какая юридическая конструкция жизни будет им заложена, она должна быть встроена в механизм правового регулирования соответствующего правопорядка.

Подводя промежуточный итог, скажем, 
что главным условием закрепления статуса «жизни» - необходимого условия существования, является бытие правопорядка, устанавливающего в соответствии со своими внутренними принципами возможность субъекта права существовать как феномену. Возможности права практически безграничны - границы накладываются лишь присущими ему внутренними законами самоорганизации. Однако правильно отмечал А.Ф. Черданцев [30], что в таком случае происходит удвоение мира. Государство и право создают определенную модель организации, которая не заменяет мир материальных вещей. Но для субъекта права это пространство становится не менее реальным. Этот мир идеальных вещей для сознающего субъекта становится способом его существования.

Вернемся к узко-специальному понимаю жизни, которое уже непосредственно связано с «правом на жизнь». Отметим, что право рассматривает жизнь с разных сторон. Кроме «права на жизнь» (биологическое существования) можно назвать «право на неприкосновенность частной жизни», «право на достойную жизнь», «право на культурную жизнь» и др. Но для правовой системы это все различные субъективные права, влекущие возникновение отличающихся друг от друга правоотношений.

Существуют несколько уровней правопорядков, которые находятся между собой в определенной степени подчинения. В рамках настоящего исследования мы будем говорить о нескольких уровнях правового регулирования: международном и государственном (национальном). На международном уровне «право на жизнь» было закреплено во Всеобщей декларации прав человека в статье 3 . Не секрет, что это субъективное право закреплено во множестве национальных конституций. Если кратко, то право на жизнь представляет собой возможность биологического существования в материальном мире.

«У Ксенофонта Кир Старший, умирая, говорит: «Не думайте, о мои горячо любимые сыновья, что я, уйдя от вас, нигде и никак не буду существовать. ... Ведь почести, оказанные прославленным мужам, не оставались бы в силе после их смерти, если бы их души не старались о том, чтобы мы и долее хранили память о них» [19, с. 155]. Существование субъекта права может продолжаться и после наступления биологической смерти. Может случиться и так, что наступление юридической смерти предшествует биологической.
Данный обычай существовал и в первобытно-общинном строе, когда лицо по какой-либо причине изгоняли из племени это наказание носило двойственный характер: с одной стороны оно символизировало смерть лица для изгнавшего племени, а с другой - вполне обычную смерть, поскольку по большому счету было приравнено к вынесению смертного приговора. Во Франции Гражданским Кодексом 1804 г. был предусмотрен институт гражданской смерти, в соответствии с которым лицо поражалось в гражданских правах и «погибало» для общества «как если бы он умер естественным образом». Естественная смерть, однако, за ней автоматически не следовала, но существовать в данном правопорядке человек уже был не в состоянии, поскольку субъект права был предан смерти. Это не мешало лицу выбрать иной правопорядок. Данная мера была отменена в середине XIX века.

Учитывая специфику нашего исследования, более подробно остановимся на таком проблеме, когда право наделяет живую материю статусом субъекта права, а если более точно, то - юридической возможностью биологического существования. Возможностью гарантируемой и охраняемой, а также могущей быть отнятой правопорядком. Плоть может быть интересна правопорядку в разном качестве, поэтому можно выделить несколько подходов: 1. Право на жизнь возникает с момента рождения, который также определен, или позднее; 2. Право на жизнь возникает до момента рождения. Иными словами, мы говорим о правовом статусе человеческого эмбриона. В первом случае эмбрион признается субъектом права физическим лицом, обладающим правами и обязанностями. Во втором же случае эмбрион представляется объектом, не обладающим самостоятельным интересом (а мы помним, что у субъекта права всегда есть собственный интересом). Его судьба зависит от субъекта и от того объема прав и обязанностей, какой дал субъекту правопорядок в отношении объекта.

Статья 17 «Гражданского кодекса Российской Федерации (часть первая)» от 30.11.1994 N 51-Ф3 (ред. От 16.12.2019, с изм. от 12.05.2020) закрепляет, что правоспособность гражданина возникает в момент его рождения. Понять же момент наступления «момента рождения» нам поможет Федеральный закон от 21.11.2011 N 323-ФЗ (ред. от 24.04.2020) «Об основах охраны здоровья граждан в Российской Федерации», который в ст. 53 «Рождение ребенка» устанавливает юридиче- 
ский факт, с которого начинается охраняемая правопорядком биологическая человеческая жизнь - момент отделения плода от организма матери. Имеются и критерии, в соответствии с которыми плод после признается живым - наличие дыхания, сердцебиения и прочее. То есть, очевидно, что материя появляется до признания за ней статуса субъекта. Нельзя не сказать и о нормативных положениях ст. 1116 Гражданского кодекса, предусматривающих, что к наследованию могут призываться лица, зачатые при жизни наследодателя и родившиеся живыми после открытия наследства. Можно давать различные этические данной норме, однако это вносит некоторое недопонимание в правовой статус человеческого плода - происходит субъект-объектное смешение, порождающее не просто возникновение правовых коллизий, но затрагивающих гораздо более глубинные основания правопорядка - нарушение нормативного равенства. Как бы то ни было, такую конструкцию будет правильнее назвать «объектной». Право также может признавать за эмбрионом статус субъекта права - самостоятельного физического лица. Например, ст. 40 Конституции Ирландии устанавливает, что государство признает право на жизнь нерожденного.

Вне зависимости от избранных морально-нравственных взглядов, считаем необходимым отметить следующее. Субъект права - это самостоятельный правовой феномен, проявляющий себя в различных правоотношениях. Нельзя признавать эмбрион субъектом только в каком-либо конкретном правоотношении. Формальная определенность и нормативность права требуют последовательное отношение со стороны конкретного правопорядка к явлению. Нет большей опасности для правопорядка, чем несогласованность юридических конструкций и противоречивость нормативных предписаний, которые расшатывают изнутри само основание правопорядка. При решении данного также нужно учитывать интересы следующих субъектов: это частный интерес матери и публичный интерес государства. В зависимости от соотношения этих интересов, правопорядок предоставляет различные правомочия в данной области.

Нельзя и не обсудить в меру своей компетенции проблемы в области технологий взаимодействия с геномом и ДНК. А если, точнее, то о возможных рисках и их последствиях.

Клонирование - это процесс воспроизводства организма или частей организ- ма, которые генетически идентичны между собой. Нельзя не согласиться с тем, что в относительно недавнем прошлом «клонирование являлось скорее предметом обсуждения писателей-фантастов, нежели научных дискуссий или общественно-политических дебатов. Стремительное развитие генной инженерии и просто таки расцвет биотехнологий в 1990-е годы создали все условия к практической возможности клонирования живых существ. Научно-технический прогресс, как часто это бывает, воплотил всё в реальность» [13]. Фантастические прогнозы действительно начинают сбываться.

Примечательно, что в России в 2002 году был принят Федеральный закон от 20 мая 2002 г. N 54-Ф3 «О временном запрете на клонирование человека», в котором ст. 1 устанавливался временный запрет сроком на 5 лет на клонирование человека. В 2010 году текст данной статьи был изменен: временный запрет продлевался «до дня вступления в силу федерального закона, устанавливающего порядок использования технологий клонирования организмов в целях клонирования человека. Спустя 10 лет такой федеральный закон так и не был принят.

Отметим, что существует несколько видов клонирования, к которым у правопорядков различное отношение.

Хотелось отдельно несколько слов сказать о технологии под названием CRISPR-Cas9, отрытой относительно недавно. C её помощью можно вносить изменения в гены, леча при этом наследственные генетические заболевания. Этот метод приобрел широкую популярность - об этом свидетельствует количество инвестиций и патентов, зарегистрированных с использование данной технологии. Однако, уже известно о том, что внесенные изменения могут передаваться будущим поколениям. Недостаточно ответственное отношение к данной технологии может привести к серьёзным негативным последствиям, поэтому следует найти правильный баланс между обсуждением и управлением с одной стороны, и содействием развитию персептивных методов с другой [2, р. 4]. Отметим, что CRISPR-Cas9 в данный момент является одной из самых перспективных способов изменения генома, но не единственным.

«Со многими новыми технологиями связаны неопределенность последствий их применения или явная опасность внедрения в практику. Наиболее угрожающим с социальной точки зрения является осно-

\section{9}

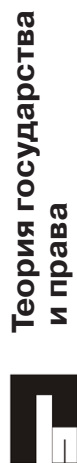


ванное на современной генетике такое направление евгеники, как искусственное выращивание людей с заданными или желательными свойствами» [16, с. 771].

Новые технологии в области генетики с одной стороны, открывают истинно невообразимые возможности. Например, в медицине - это лечение не только различного рода генетических заболеваний но также и более распространенных и типичных болезней. В сельскохозяйственной генетике научные открытия позволяют решать проблему недостаточности пищи. И намного больше преимуществ человечество может получить в дальнейшем.

Однако за очевидными преимуществами следуют также и опасности. Речь идет не только о создании оружия, хотя и это не исключено. Непродуманные действия в области работы с геномом человека могут привести к совершенно неудовлетворительным результатам. История знает не один пример, когда на государственном уровне решения принимались без соответствующего анализа. За этими решениями следуют социальные, экономические, политические кризисы. Не говоря уже о личных трагедиях.

Снизить риски и получить максимум пользы помогут комплексные междисциплинарные исследования. Но мало их организовать - государство и общество должно к ним прислушаться.

Нельзя не сказать о том, что Российская Федерация принимает нормативные акты, которые регулируют развитие науки в области генетических исследований. Во-первых, скажем об Указе Президента Российской Федерации от 28.11.2018 г. № 680»О развитии генетических технологий в Российской Федерации»(вместе с «Положением о совете по реализации Федеральной научно-технической программы развития генетических технологий на 2019 - 2027 годы»), согласно которому Правительству России было необходимо в ближайшие сроки разработать программу развития генетических технологий, что и было сделано.В начале 2019 года была принята Федеральная научнотехническая программа развития генетических технологий на 2019 - 2027 г., основными целями которой являются комплексное решение задач ускоренного развития генетических технологий, в том числе технологий генетического редактирования, и создание научно-технологических заделов для медицины, сельского хозяйства и промышленности, а также совершенствование мер предупреждения чрезвычайных ситуаций биологического характера и контроля в этой области. Иными словами, государство поставило целью сократить отставание в области генной инженерии, а новые знания намерено направить в сельское хозяйство, медицину и промышленность. Надеемся, что разворачивающийся на наших глазах мировой финансовый кризис не помешает достижений целей данной программы. Тем не менее, сам факт наличия стремления у государства стимулирования развития данных областей науки. «Регламентация разнообразных аспектов науки является одним из условий ее успешного развития. Роль законодательства в обеспечении развития научной деятельности предполагает создание оптимального правового режима, регламентирующего деятельность ее субъектов, защищающего их права и законные интересы. При этом правовое регулирование должно обеспечивать достижение телеологических установок, которые, в конечном счете, определяют содержание юридических норм» 6 , с. 26].

Наука изменяет наше восприятие мира, представляет человечеству самые удивительные вещи, кажущимися порой даже непостижимыми и фантастическими. Достижения естественных наук очевидно изменяют нашу жизнь с нашими мировоззренческими установками. Научные открытия внедряются в жизненный уклад общества по-разному: некоторые после продолжительных обсуждений, а некоторые спонтанно; часть практик впоследствии признается успешными, а часть ошибочными. Юриспруденция должна предоставлять адекватный ответ на технологические вызовы, как на уровне теории, так и на уровне нормативной организации. Во втором право, как система предусматривает механизм реакции на вхождение в свою сферу новых элементов, у которых предварительно отсутствует правовой статус и соответствующее правовое регулирование.

Закончить нашу работу мы бы хотели словами Н.М. Коркунова, которые содержались во введении к Лекциям по общей теории права: «Развитие общественной жизни приносит с собою все большее и большее осложнение тех разнообразных, сталкивающихся между собою человеческих интересов, разграничение которых составляет задачу права. В сложной общественной жизни одни и те же интересы могут становиться друг к другу в самые разнообразные отношения, и каждая форма их взаимного соотношения требует для своего разграничения особой юридической нормы» [14, с. 6]. 


\section{Литература}

1. Amy L. McGuire, JD, PhD1, Jennifer A. Hamilton, PhD3, Rebecca Lunstroth, JD, MA4, Laurence B. McCullough, PhD, and Alica Goldman, MD, PhD DNA data sharing: research participants' perspectives // Genetic in Medicine, 2008, Vol. 10, No. 1.

2. Being Human: The Ethics, Law, and Scientific Progress of Genome Editing // Australian Quarterly, 2016. 87(1).

3. Erin D. Williams Informed Consent in Genetic Research // Croatian medical journal, 2001, № 42 (4).

4. Karen J. Maschke, "Biobanks: DNA and Research," in From Birth to Death and Bench to Clinic: The Hastings Center Bioethics Briefing Book for Journalists, Policymakers, and Campaigns, ed. Mary Crowley (Garrison, NY: The Hastings Center, 2008).

5. Бабаджанов И.Х., Сальников С.П. «Жизнь» как юридическая категория и явление природы // Вестник Академии экономической безопасности МВД России. 2010. № 9.

6. Берг Л.Н. Проблемы законодательного обеспечения научной деятельности в России // Актуальные проблемы российского права. 2015. № 1 (50).

7. БИОЭТИКА//URL:https://www.krugosvet.ru/enc/medicina/BIOETIKA.html(дата обращения: 11.06 .2020$)$

8. Биоэтика как новый тип знания //URL: https://postnauka.ru/video/52406 (дата обращения: 11.06 .2020$)$

9. Вирусолог назвал сроки создания безопасной вакцины от коронавируса// РБК. 11 апр. 2020. URL: https://www.rbc.ru/rbcfreenews/5e91652f9a79471fbb1 d9913 (дата обращения: 11.06.2020)

10. Всеобщая декларация о биоэтике и правах человека (Принята резолюцией Генеральной конференции ЮНЕСКО по докладу Комиссии III на 18-м пленарном заседании 19 октября 2005 года.)

11. Всеобщая декларация о геноме человека и правах человека (Принята 11 ноября 1997 года Генеральной конференцией Организации Объединенных Наций по вопросам образования, науки и культуры).

12. Генетика: основные понятия и диагностика //URL:https://oxy-center.ru/fordoctors/specialistam/genetika-osnovnye-ponyatiya-i-diagnostika/(дата обращения: 11.06.2020).

13. Калиниченко П.А. Запрет клонирования человека в европейском праве // URL: https://eulaw.edu.ru/publikatsii/stati-po-pravu-evropejskogo-soyuza/zapretklonirovaniya-cheloveka-v-evropejskom-prave-p-a-kalinichenko/ (дата обращения: 14.05.2020).

14. Коркунов Н.М. Лекции по общей теории права : Юридический центр; СанктПетербург; 2004.

15. Логика достоинства и свободы личности :посвящ. 85-летию Ин-та филос. НАН Беларуси / сост. и науч. ред. Л. Ф. Евменов. Минск: Беларускаянавука, 2016.

16. Лопухин Ю.М. Биоэтика в России // Вестник Российской Академии Наук, 2001, том 71, М 9

17. Лоуренс Р. Холокост: Новая история - М.: КоЛибри, Азбкуа-Аттиус, 2018.

18. Международная декларация о генетических данных человека (Принята резолюцией Генеральной конференции ЮНЕСКО по докладу Комиссии III на 20-м пленарном заседании 16 октября 2003 года).

19. Моральные размышления о старости, о дружбе, об обязанностях. Готовому перейти Рубикон / Марк Туллий Цицерон. - М.: РИПОЛ классик, 2016.

20. Новая философская энциклопедия. В четырех томах. / Ин-т философии РАН. Научно-ред. совет: В.С. Степин, А.А. Гусейнов, Г.Ю. Семигин. М., Мысль, 2010 , т. I, А - Д.

21. Нюрнбергский процесс по делу медицинских преступлений в ходе Второй мировой войны // TACC. 8 дек. 2016. URL: https://tass.ru/info/3854974 (дата обращения: 11.06.2020).

22. Перевалов В.Д. Взаимодействие правовых систем: теоретические аспекты // Российский юридический журнал. 2014. № 5 (98).

23. Пестрикова А.А. Формирование правовых принципов в области генной инженерии и биомедицинских технологий // Вестник Самарской гуманитарной академии. Серия «Право». 2018. №1 (20).

24. Положение о Российском комитете по биоэтике при комиссии Российской Федерации поделами ЮHЕСКО //URL:http://www.bioethics.ru/rus/staff/ (дата обращения: 11.06.2020).

25. Проект «Геном человека»: десять лет спустя //URL:https:/elementy.ru/ nauchno-populyarnaya_biblioteka/431280/Proekt_Genom_cheloveka_desyat_let_ spustya(дата обращения: 11.06.2020).

26. Руководство № 1 по созданию комитетов по биоэтике // URL: https:// unesdoc.unesco.org/ark:/48223/pf0000139309_rus (дата обращения: 11.06.2020).

27. Савченко В.К. Проект «Геном человека» и права личности // ВесціНацыяна льнайАкадэмііНавукБеларусі. Серыягуманітарныхнавук. 2013. № 3.

28. США официально извинились за медицинские опыты над людьми в Гва- 
темале// РИА Новости. 2 окт. 2010. URL: https://ria.ru/20101002/281411901. html? in=t(дата обращения 11.06.2020).

29. Хельсинкская декларация Всемирной медицинской ассоциации (Принята на 18-й Генеральной ассамблее Всемирной медицинской ассоциации (WorldMedicalAssociation - WMA), Хельсинки, Финляндия, июнь 1964 г.

30. Черданцев А. Ф. Логико-языковые феномены в юриспруденции : монография. - М. : Норма: ИНФРА-М. 2012. - 320 с.

\section{References}

1. AmyL. McGuire, JD, PhD1, JenniferA. Hamilton, PhD3, RebeccaLunstroth, JD, MA4, Laurence B. McCullough, PhD, and Alica Goldman, MD, PhD DNA data sharing: research participants' perspectives // Genetic in Medicine, 2008, Vol. 10, No. 1 2. Being Human: The Ethics, Law, and Scientific Progress of Genome Editing // Australian Quarterly, 2016. 87(1).

3. Erin D. Williams Informed Consent in Genetic Research // Croatian medical journal, 2001, № 42 (4.

4. Karen J. Maschke, "Biobanks: DNA and Research," in From Birth to Death and Bench to Clinic: The Hastings Center Bioethics Briefing Book for Journalists, Policymakers, and Campaigns, ed. Mary Crowley (Garrison, NY: The Hastings Center, 2008).

5. Babadzhanovl.Kh., Sal'nikov S.P. «Zhizn'» kakyuridicheskayakategoriyaiyavleni eprirody // VestnikAkademiiekonomicheskoibezopasnosti MVD Rossii. 2010. № 9. 6. Berg L.N. Problemyzakonodatel'nogoobespecheniyanauchnoideyatel'nosti v Rossii // Aktual'nyeproblemyrossiiskogoprava. 2015. № 1 (50).

7. BIOETIKA // URL: https://www.krugosvet.ru/enc/medicina/BIOETIKA.html (data obrashcheniya: 11.06.2020)

8. Bioetikakaknovyi tip znaniya // URL: https://postnauka.ru/video/52406 (data obrashcheniya: 11.06.2020)

9. Virusolognazvalsrokisozdaniyabezopasnoivaktsinyotkoronavirusa // RBK. 11 apr. 2020. URL: https://www.rbc.ru/rbcfreenews/5e91652f9a79471fbb1d9913 (data obrashcheniya: 11.06.2020)

10. Vseobshchayadeklaratsiya o bioetikeipravakhcheloveka (PrinyatarezolyutsieiG eneral'noikonferentsiiYuNESKOpodokladuKomissii III na 18-m plenarnomzasedanii 19 oktyabrya 2005 goda.)

11. Vseobshchayadeklaratsiya o genome chelovekaipravakhcheloveka (Prinyata 11 noyabrya 1997 godaGeneral'noikonferentsieiOrganizatsiiOb"edinennykhNatsiipovo prosamobrazovaniya, naukiikul'tury).

12. Genetika: osnovnyeponyatiyaidiagnostika // URL: https://oxy-center.ru/ for-doctors/specialistam/genetika-osnovnye-ponyatiya-i-diagnostika/ (data obrashcheniya: 11.06.2020).

13. Kalinichenko P.A. Zapretklonirovaniyacheloveka v evropeiskomprave // URL: https://eulaw.edu.ru/publikatsii/stati-po-pravu-evropejskogo-soyuza/ zapret-klonirovaniya-cheloveka-v-evropejskom-prave-p-a-kalinichenko/ (data obrashcheniya: 14.05.2020)

14. Korkunov N.M. Lektsiipoobshcheiteoriiprava :Yuridicheskiitsentr; SanktPeterburg; 2004.

15. Logikadostoinstvaisvobodylichnosti :posvyashch. 85-letiyu In-ta filos. NAN Belarusi / sost.inauch. red. L. F. Evmenov. Minsk :Belaruskayanavuka, 2016.

16. LopukhinYu.M. Bioetika v Rossii // VestnikRossiiskoiAkademiiNauk, 2001, tom 71, M 9.

17. Lourens R. Kholokost: Novaya istoriya - M.: KoLibri, Azbkua-Attius, 2018.

18. Mezhdunarodnayadeklaratsiya o geneticheskikhdannykhcheloveka (Priny atarezolyutsieiGeneral'noikonferentsiiYuNESKOpodokladuKomissii III na 20-m plenarnomzasedanii 16 oktyabrya 2003 goda).

19. Moral'nyerazmyshleniya o starosti, o druzhbe, obobyazannostyakh. GotovomupereitiRubikon / Mark TulliiTsitseron. - M.: RIPOL klassik, 2016.

20. Novaya filosofskayaentsiklopediya. V chetyrekhtomakh. / In-t filosofii RAN. Nauchno-red.sovet: V.S. Stepin, A.A. Guseinov, G.Yu. Semigin.M., Mysl', 2010, t.I, A - D.

21. Nyurnbergskii protsess po delu meditsinskikh prestuplenii v khode Vtoroi mirovoi voiny // TASS. 8 dek. 2016. URL: https://tass.ru/info/3854974 (data obrashcheniya: 11.06.2020).

22. Perevalov V.D. Vzaimodeistviepravovykhsistem: teoreticheskieaspekty // Rossiiskiiyuridicheskiizhurnal. 2014. № 5 (98).

23. Pestrikova A.A. Formirovaniepravovykhprintsipov v oblastigennoiinzheneriiibiom editsinskikhtekhnologii // VestnikSamarskoigumanitarnoiakademii. Seriya «Pravo». 2018. №1 (20).

24. Polozhenie o RossiiskomkomitetepobioetikeprikomissiiRossiiskoiFederatsiipo delamiYuNESKO // URL: http://www. bioethics.ru/rus/staff/ (data obrashcheniya: 11.06.2020).

25. Proekt «Genomcheloveka»: desyat' let spustya // URL: https://elementy.ru/ nauchno-populyarnaya_biblioteka/431280/Proekt_Genom_cheloveka_desyat_let_ spustya (data obrashcheniya: 11.06.2020). 
26. Rukovodstvo № 1 posozdaniyukomitetovpobioetike // URL: https://unesdoc. unesco.org/ark:/48223/pf0000139309_rus (data obrashcheniya: 11.06.2020).

27. Savchenko V.K. Proekt «Genomcheloveka» ipravalichnosti // VestsiNatsyyanal' naiAkademiiNavukBelarusi. Seryyagumanitarnykhnavuk. 2013. № 3.

28. SShAofitsial'noizvinilis' zameditsinskieopytynadlyud'mi v Gvatemale // RIA Novosti. 2 okt. 2010. URL: https://ria.ru/20101002/281411901.html?in=t (data obrashcheniya 11.06.2020).

29. Khel'sinkskayadeklaratsiyaVsemirnoimeditsinskoiassotsiatsii (Prinyatana 18-i

General'noiassambleeVsemirnoimeditsinskoiassotsiatsii (World Medical Association - WMA), Khel'sinki, Finlyandiya, iyun' 1964.

30. Cherdantsev A. F.Logiko-jazykovyefenomeny v jurisprudencii - M.: Norma: INFRA-M, 2012.

ТИщЕНКО Владислав Валерьевич, преподаватель кафедры теории государства и права, Уральский государственный юридический университет. 620137, Свердловская область, г. Екатеринбург, ул. Комсомольская, 21. E-mail: fox_spirit_1912@mail.ru

TISHCHENKO Vladislav Valerievich, Lecturer of Theory of State and Law Departmen, Ural State Law University. 620137, Sverdlovsk region, Ekaterinburg, st. Komsomolskaya, 21. E-mail: fox_spirit_1912@mail.ru 